\title{
'Imperial' melon plant seedlings initial development in function of boron doses applied in the seed
}

\section{Desenvolvimento inicial de mudas de meloeiro 'imperial' em função de doses de boro aplicadas na semente}

\author{
Francisca Gislene ALBANO'; Raissa Rachel Salustriano da SILVA-MATOS²; \\ Ítalo Herbert Lucena CAVALCANTE³; Roberto Lustosa SILVA4; Adenaelson de Sousa MARQUES ${ }^{5}$; \\ Leonel Soares da $\operatorname{COSTA}^{5}$ \\ 1 Eng. Agr. Mestranda em Fitotecnia - Universidade Federal do Piauí, CPCE/UFPI, Bom Jesus-PI. E-mail: \\ gislene_fga@hotmail.com \\ 2 M.Sc. Doutoranda em Ciência do Solo - Universidade Federal da Paraíba - CCA/UFPB, Areia-PB. E-mail: \\ raissasalustriano@yahoo.com.br \\ 3 Prof. Dr.; Universidade Federal do Vale do São Francisco, Campus de Ciências Agrárias, CEAGRO/UNIVASF, \\ Petrolina, PE. E-mail: italo.cavalcante@univasf.edu.br \\ ${ }^{4}$ Autor para correspondência - M.Sc. Doutorando em Solos e Nutrição de Plantas, Departamento de Solos, UFV, \\ Universidade Federal de Viçosa, Ed. Arthur Bernardes, s/n - 1ㅇandar - sl. 116, 36570-000; Viçosa-MG. E-mail: \\ robertolustosa88@gmail.com \\ ${ }^{5}$ Acadêmicos do curso de Engenharia Agronomia - Universidade Federal do Piauí, CPCE/UFPI, Bom Jesus-PI. E-mail: \\ kdadenaelson@gmail.com; ea.leonel@gmail.com
}

Recebido em: 29-09-2014; Aceito em: 05-05-2015

\begin{abstract}
The melon has little boron deficiency tolerance and supply as seed treatment can meet the need of the plant and improve its development especially in the seedling stage. The objective of this study was to evaluate the initial development of muskmelon seedlings 'Imperial' on the basis of boron application in seeds. The experiment was conducted under greenhouse conditions (50\% brightness) in Bom Jesus-PI in the period April-May 2011. It was adopted a randomized block design, with treatments: 0.0; 4.24; 8.50; $17.00 ; 34.00 \mathrm{~g} \mathrm{~kg}^{-1} \mathrm{~B}$ seeds, with five replications, and experimental unit consisting of five seedlings. Tubes were used as containers for up to $50 \mathrm{~cm}^{-3}$, filled with a substrate composed of soil (Oxisol), washed sand and manure in the ratio (1:1:2) respectively. At the end of the experiment were evaluated: i) plant height; ii) stem diameter and iii) dry matter of root and shoot. There was an effect of boron rates applied to melon seed, with increased production of dry matter of shoots and roots, recommending the dose $11 \mathrm{~g} \mathrm{~B}$ per $\mathrm{kg}$ of seed for increased production of dry tissue.
\end{abstract}

Additional keywords: boric acid; Cucumis melo L.; seed fertilization.

\section{Resumo}

O meloeiro apresenta pouca tolerância à deficiência de boro, e seu fornecimento via tratamento de sementes pode atender à necessidade da planta e melhorar seu desenvolvimento, especialmente na fase de mudas. Objetivou-se com este trabalho avaliar o desenvolvimento inicial de mudas de meloeiro 'Imperial' em função da aplicação de boro nas sementes. O experimento foi realizado em abrigo telado ( $50 \%$ de luminosidade), em Bom Jesus-PI, no período de abril a maio de 2011. Adotou-se delineamento em blocos casualizados, com os tratamentos: 0,$0 ; 4,24 ; 8,50 ; 17,00$ e 34,00 gramas de B por quilograma de sementes, com cinco repetições, e parcela experimental constituída por cinco plântulas. Foram utilizados como recipientes tubetes com capacidade para $50 \mathrm{~cm}^{-3}$, preenchidos com substrato constituído de solo (Latossolo Vermelho), areia lavada e esterco bovino, na proporção (1:1:2), respectivamente. No final do experimento, avaliaram-se: i) altura da planta; ii) diâmetro do caule, e iii) matéria seca de raiz e da parte aérea. Houve efeito das doses de boro aplicadas via semente de melão, com aumento na produção de matéria seca da parte aérea e radicular, recomendando-se a dose de $11 \mathrm{~g}$ de $\mathrm{B}$ por kg de semente para maior produção de matéria seca das mudas.

Palavras-chave adicionais: ácido bórico; adubação via semente; Cucumis melo L.

\section{Introduction}

Melon (Cucumis melo L.) is a very appreciated and consumed vegetable, mainly in natura. In Brazil, approximately 566,000 melon tons were produced in 2013, with northeastern Brazil being the region that produced more, where of Rio Grande do
Norte and Ceará states accounted for 254,530 and 212,362 melon tons, having 28.7 and $28.9 \mathrm{t} \mathrm{ha}^{-1}$ mean yields, respectively (IBGE, 2013). The state of Piauí has little participation in melon production. However, it has a mean yield of $29.8 \mathrm{t} \mathrm{ha}^{-1}$ (IBGE, 2013), showing potential for this crop cultivation.

In an orchard implementation, seedlings qual- 
ity is essential to ensure uniformity, rapid formation and crop establishment. Additionally, in order to obtain good quality seedlings, the adoption of good practices of water demand, plant health, suitable substrate and nutrient supply are essential cultural practices to the crop success (Prado et al., 2006).

Among micronutrients, boron $(B)$ is one of those that have higher deficiency occurrences in Brazilian crops (Marchetti et al., 2001; Prado et al., 2006). The same authors also claimed that the $B$ amount applied per seedling is very small, generating a high cost-benefit ratio in seedling production systems.

B deficiency causes development, growth and seedling quality reductions, in addition to crop yield reduction. It also causes physiological and biochemical changes, such as cell wall structure, membranes functioning and integrity changes, enzyme activity changes and altered production of a series of plant metabolite processes (Echer et al., 2009). There is evidence that plants in initial growth state absorb B with higher intensity than adult plants, as B shows little redistribution mobility of old tissues for younger (Sousa et al., 2011).

Based on this nutrient small amount required by plants, fertilization through seeds can be a good choice due to its lower application costs, better uniformity in the distribution of this micronutrient and
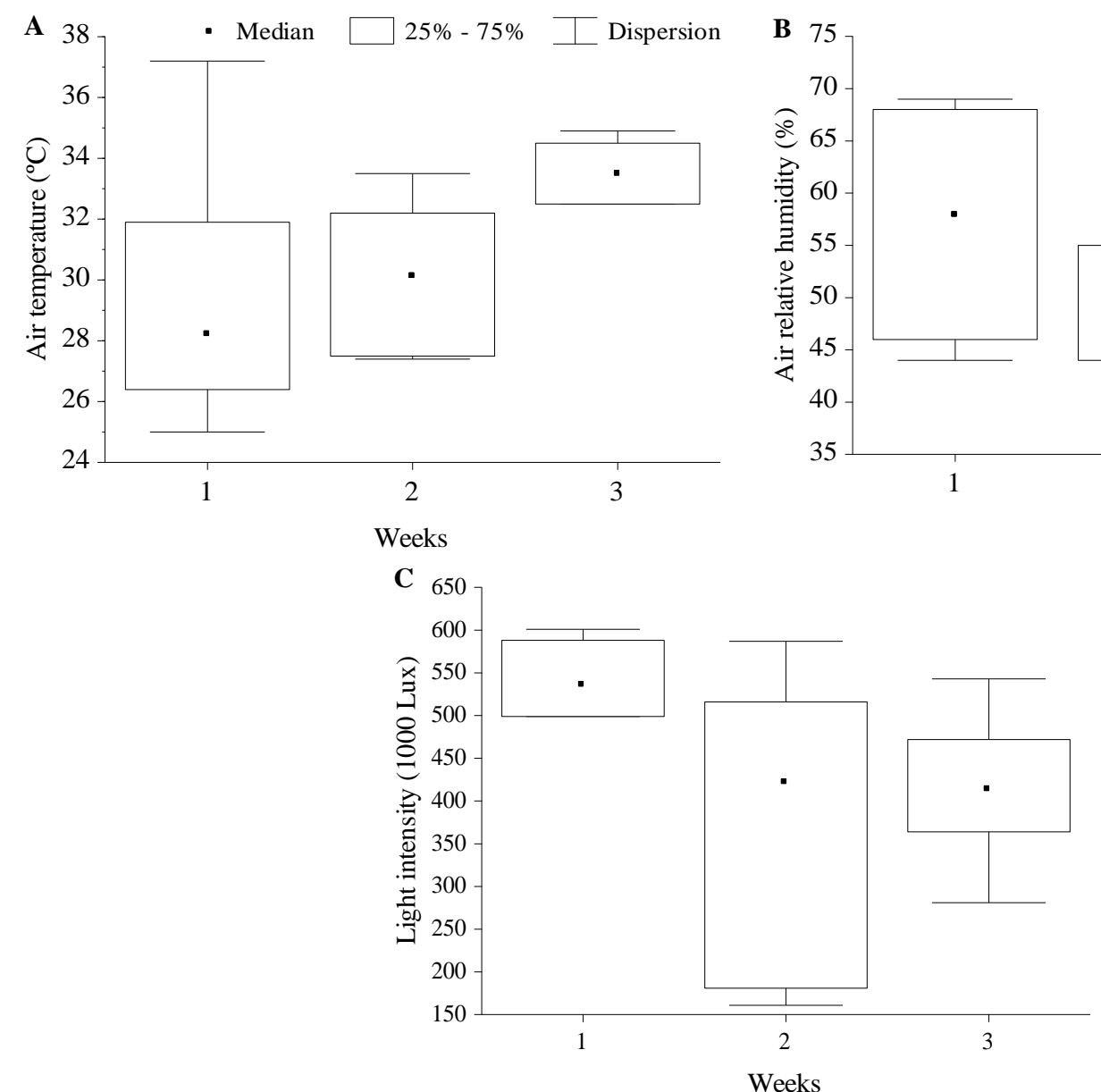

Figure 1 - Mean air temperature $(A)$, air humidity $(B)$ and light intensity $(C)$ weekly dispersion diagram inside the greenhouse during the experiment execution.

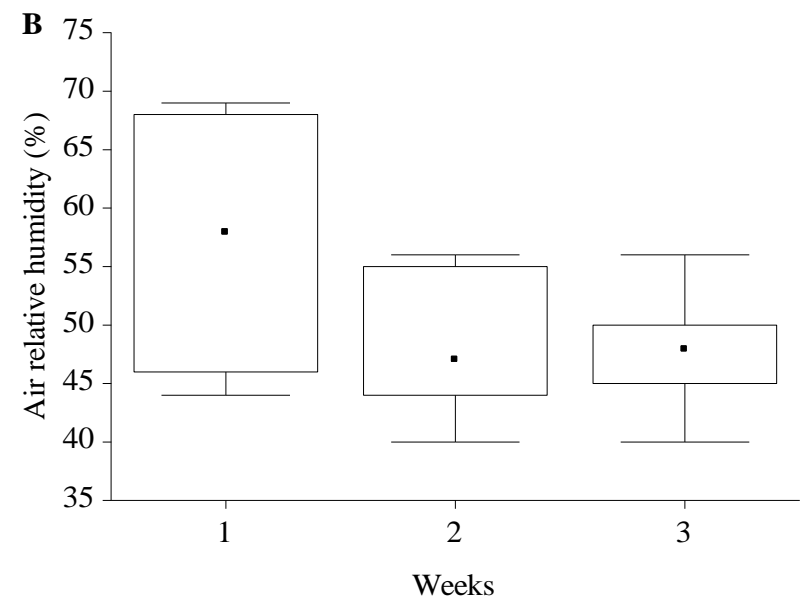

lower leaching losses. Thus, boron provision via seeds treatment may be an alternative to supply this nutrient during plants initial development, with positive effects on initial plant growth and development and, consequently, on plants production with improved quality (Ohse et al., 2001).

Studies on boron effect applied via seeds treatment in melon plant seedlings formation are scarce in the literature, with studies only in major crops, such as corn (Avila et al., 2006) and rice (Bays et al., 2007), with promising results.

In this sense, the aim of the present study was to assess 'imperial' melon plant seedlings initial development in function of boron doses applied in the seeds.

\section{Material and methods}

The experiment was conducted from April to May 2011 under greenhouse conditions (50\% luminosity) on "Prof. Cinobelina Elvas" Campus, Federal University of Piauí, Bom Jesus, PI state.

During the experiment execution, air temperature and humidity (Instrutemp ${ }^{\circledR}$ thermohygrometer, Brazil) and light (Instrutherm ${ }^{\circledR}$ digital light meter) climatic data inside the greenhouse were collected (Figure 1).

\footnotetext{
the greenhouse during the experiment execution.
} 
The design was of randomized blocks with the following treatments: $0.0 ; 4.24 ; 8.50 ; 17.00$; $34.00 \mathrm{~g} \mathrm{~B}$ to $1 \mathrm{~kg}$ seeds, defined as recommended by Malavolta et al. (1981), with five repetitions. The experimental plot was composed of five 'imperial' melon seedlings. The boron source used was boric acid $\left(17 \mathrm{~g} \mathrm{~kg}^{-1} \mathrm{~B}\right)$ diluted in water $(15 \mathrm{~mL}$ deionized water per seed $\mathrm{kg}$ ), in which seeds were moistened; after observing that all the boric acid solution was absorbed by the seeds, sowing proceeded. Tubes with $50 \mathrm{~cm}^{-3}$ capacity were used as containers, being filled with soil substrate (Oxisol) collected in the 0.20 to $0.40 \mathrm{~m}$ depth, washed sand and cattle manure. The manure was added to promote better washed sand aggregation to the substrate remainder, and the (1:1:2) ratio was used, respectively. Soil and cattle manure chemical analysis was carried out according to the method described in EMBRAPA (1997) (Table 1). Cultivation was summarized in irrigation, held daily with deionized water through daily weighing method, in order to maintain the recipients in $80 \%$ field capacity (Corrêa et al., 2013), ensuring no water excess to be drained, thus avoiding $B$ loss by leaching due to its high soil mobility.

Table 1 - Soil and manure used in the experiment chemical characteristics.

\begin{tabular}{|c|c|c|}
\hline Attributes & Soil & $\begin{array}{l}\text { Cattle } \\
\text { manure }\end{array}$ \\
\hline $\mathrm{pH}$ (water) & 5.3 & 9.1 \\
\hline $\mathrm{B}\left(\mathrm{mg} \mathrm{dm}^{-3}\right)$ & 0.4 & 2.0 \\
\hline $\mathrm{Ca}^{2+}+\mathrm{Mg}^{2+}\left(\mathrm{cmol}_{\mathrm{c}} \mathrm{dm}^{-3}\right)$ & 0.56 & 5.90 \\
\hline $\mathrm{Ca}^{2+}\left(\mathrm{cmol}_{\mathrm{c}} \mathrm{dm}^{-3}\right)$ & 0.32 & 4.40 \\
\hline $\mathrm{K}^{+}\left(\mathrm{cmol}_{\mathrm{c}} \mathrm{dm}^{-3}\right)$ & 0.01 & 2.78 \\
\hline $\mathrm{Na}^{+}\left(\mathrm{cmol}_{\mathrm{c}} \mathrm{dm}^{-3}\right)$ & 0.01 & 19.58 \\
\hline $\mathrm{H}^{+}+\mathrm{Al}^{3+}\left(\mathrm{cmol}_{\mathrm{c}} \mathrm{dm}^{-3}\right)$ & 1.10 & 2.97 \\
\hline Organic matter $\left(\mathrm{g} \mathrm{kg}^{-1}\right)$ & 2.3 & 156.0 \\
\hline
\end{tabular}

$\mathrm{K}, \mathrm{Na}$ : Melich1; $\mathrm{H}+\mathrm{Al}$ : calcium acetate extractor $0.5 \mathrm{M}$, $\mathrm{pH}$ 7; $\mathrm{Ca}, \mathrm{Mg}: \mathrm{KCl} 1 \mathrm{M}$.

At the end of the experiment, which occurred at 25 days after sowing, the following variables were recorded: i) plant height $(\mathrm{cm})$ : measured from the plant base to the youngest leaf insertion; ii) stem diameter, obtained with a digital caliper and iii) root and shoot dry matter ( $\mathrm{g} \mathrm{plant}^{-1}$ ): obtained by oven drying method, with forced air at $70{ }^{\circ} \mathrm{C}$ temperature until reaching constant weight (about 48 hours), when roots and shoots were separately weighed in a precision scale ( $0.01 \mathrm{~g}$ accuracy).

The data were submitted to analysis of variance through " $F$ " test, and those variables with significant effect were submitted to polynomial regression analysis in the SigmaPlot software.

\section{Results and discussions}

There was B doses significant effect applied to seeds for all variables.

Melon seedlings height was increased with increasing $B$ doses applied to seeds up to the dose of $17.0 \mathrm{~g} \mathrm{~B} \mathrm{~kg}^{-1}$ of seed, decreasing with increasing $B$ doses in the seed (Figure 2A). These results can be explained by the fact that $B$ adequate supply promotes shoot growth points elongation, thus promoting plant growth (Prado, 2008), as well as the excess causes deleterious effect to the plants. Additionally, Ohse et al. (2001) stated that B applied via seeds plays a key role as a growth promoter, what will result in plant height increase.

There was stem diameter decrease with increasing $B$ doses via seed (Figure 2B), which is a result that disagrees with findings of Silva (2005), who found that 1 to $3 \mathrm{~kg}^{-1}$ boron doses applied via seed have not affected sunflower stems diameter. However, these results also contrast with Lima et al. (2013), who studied sunflower crop borated application via seeds and found increment for this variable at $2.1 \mathrm{~mL} \mathrm{~kg}^{-1}$ seeds dosage, which was a higher result than that of the highest applied dose (3.2 $\mathrm{mL} \mathrm{kg}^{-1}$ seeds).

It was observed that $B$ doses increase promoted shoot dry matter increase up to $12.3 \mathrm{~g}$ boron per $\mathrm{kg}$ seeds dose, followed by a small decrease with increased boron application (Figure 2C). Possibly, the mean B content existing in the soil (Table 1) represented a suitable element amount required for the crop. In this sense, Pessoa et al. (2000) stated that the germinating seed, due to not having efficient physiological mechanisms to control B input via seed soaking, which occurs passively, may accumulate toxic concentrations of this element and have phytotoxicity. B is directly related to meristematic growth and hormones activity, which stimulate young plant parts development and elongation (Soltani \& Sinclair, 2012).

Boron treatments applied through melon seeds increased root dry matter up to a dose of $10.5 \mathrm{~g}$ boron $\mathrm{kg}^{-1}$ seeds, and from this dose root dry matter content reduced (Figure 2D). In this sense, Demiray \& Dereboylu (2013) stated that higher B doses on the substrate caused a significant reduction in root tissue lignification, as well as negatively impacted on xylem formation, characteristics that directly and negatively influence root development.

Values found for the root dry matter variable agree with results reported by Prado et al. (2006), where $0.5 \mathrm{mg} \mathrm{dm}^{-3} \mathrm{~B}$ applied to the substrate promoted yellow passion fruit seedlings maximum root dry matter productivity. However, this study results disagree with Wazilewski \& Gomes (2009) findings, who working with different $B$ doses applied to sunflower seeds, have not found significant mean difference between treatments for root dry matter variable. 

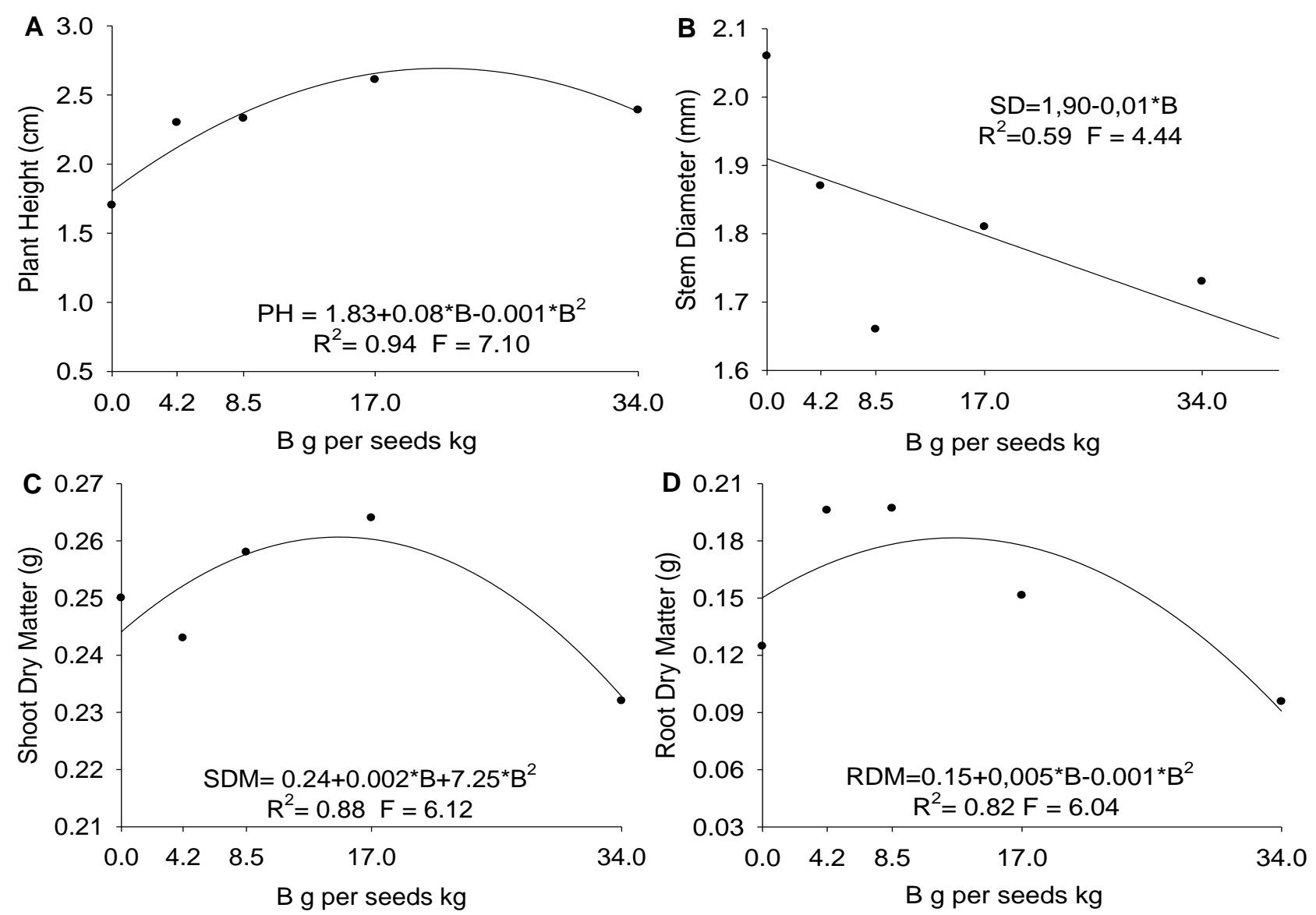

Figure 2 - Melon seedlings plant height (A), stem diameter (B), shoot dry matter (C) and root dry matter (D) in function of seeds boron fertilization.

\section{Conclusions}

There was boron doses applied to 'imperial' melon plant seeds influence, having a satisfactory initial development, with no visible toxicity symptoms caused by B. Boron doses promoted shoots and roots dry matter production increase, and the dose of $11 \mathrm{~g} \mathrm{~B}$ per seed $\mathrm{kg}$ is recommended for higher seedlings dry matter production.

\section{References}

Ávila MR, Braccini AL, Scapim CA, Martorelli DT, Albrecht LP, Faciolli FS (2006) Qualidade fisiológica e produtividade das sementes de milho tratadas com micronutrientes e cultivadas no período de safrinha. Acta Scientiarum. Agronomy 28(4):535-543. doi: 10.4025/actasciagron.v28i4.927

Bays $R$, Baudet L, Henning AA, Lucca Filho $O$ (2007) Recobrimento de sementes de soja com micronutrientes, fungicida e polímero. Revista Brasileira de Sementes 29(2):60-67. doi: 10.1590/S0101-31222007000200009

Corrêa VB, Pezzopane JEM, Xavier TMT, Toledo JV, Schwider YS (2013) Determinação da umidade para o desenvolvimento de mudas de eucalipto sob diferentes regimes térmicos. Enciclopédia Biosfera $9(16): 711-722$.
Demiray H, Dereboylu AE (2013) Effects of excess and deficient boron and niacin on the ultrastructure of root cells in Daucuscarota cv. Nantes.Turkish Journal of Botany 37(1):160-166. doi:10.3906/bot1202-22

Echer FR, Dominato JC, Creste JE, Santos DH (2009) Fertilização de cobertura com boro e potássio na nutrição e produtividade da batata-doce. Horticultura Brasileira 27(2):171-175. doi: $10.1590 / \mathrm{S} 0102-05362009000200009$

EMBRAPA - Empresa Brasileira de Pesquisa Agropecuária (1997). Centro Nacional de Pesquisa de Solos. Manual de métodos de análise de solo, Rio de Janeiro. 212 p.

IBGE - Instituto Brasileiro de Geografia e Estatística (2013) Estados/Culturas Temporárias/Melão. Disponível em: <http://www.ibge.gov.br/estadosat/>. Acesso em: 15 jan. 2013

Lima AD, Viana TVA, Azevedo BM, Marinho AB, Duarte JML (2013) Adubação borácica na cultura do girassol. Revista Agro@mbiente On-line 7(3):69-276.

Malavolta E (1981) Manual de química agrícola: adubos e adubação. Agronômica Ceres, 594 p. 
Marchetti ME, Motomya WR, Fabrício AC, Novelino JO (2001) Resposta do girassol, Helianthusannuus, a fontes e níveis de boro. Acta Scientiarum. Agronomy 23(5):1107-1110. doi: 10.4025/actasciagron.v23i0.2566.

Ohse S, Morodim V, Santos OS, Lopes SJ, Mafron AP (2001) Germinação e vigor de sementes de arroz irrigado tratadas com zinco, boro e cobre. Revista da Faculdade de Zootecnia, Veterinária e Agronomia 8(1):41-50.

Pessoa ACS, Luchese EB, Luchese AV (2000) Germinação e desenvolvimento inicial de plantas de milho, em resposta ao tratamento de sementes com boro. Revista Brasileira de Ciência do Solo, 24(4):939945. doi: doi.org/10.1590/S0100-06832000000400025

Prado RM, Natale W, Rozane DE (2006) Níveis críticos de boro no solo e na planta para cultivo de mudas de Maracujazeiro-amarelo. Revista Brasileira de Fruticultura 28(2):305-309. doi: 10.1590/S010029452006000200034.
Prado RM (2008) Nutrição de Plantas, UNESP. 408 p.

Silva MLO (2005) Aplicações de lâminas de água e doses de boro na cultura do Girassol. Ufla (Tese de doutorado em Engenharia Agrícola).

Soltani A, Sinclair TR (2012) Modeling physiology of crop development, growth and yield. CABI, $368 \mathrm{p}$.

Sousa GG, Novelino JO, Scalon SQP, Marchetti ME (2011) Crescimento de mudas de maracujazeiro em função de adubação à base de boro e material de cupinzeiro. Pesquisa Agropecuária Tropical 41(2):170-178. doi: 10.5216/pat.v41i2.7980.

Wazilewski WT, Gomes LFS (2009) Boro aplicado via semente em girassol. Cultivando o Saber 2(2):137-142. 